\title{
PERBANDINGAN PEMERIKSAAN IgM ANTI SALMONELLA TYPHI DENGAN METODE ICT DAN ELISA PADA PASIEN WIDAL POSITIF
}

\author{
Alpian Jayadi*1, Jusak Nugraha ${ }^{2}$, Marijam Purwanta ${ }^{3}$ \\ ${ }^{1}$ Departemen S2 Imunologi Sekolah Pascasarjana Universitas Airlangga Surabaya \\ ${ }^{2}$ Departemen Patologi Klinik Fakultas Kedokteran Universitas Airlangga Surabaya \\ ${ }^{3}$ Departemen Mikrobiologi Fakultas Kedokteran Universitas Airlangga Surabaya \\ Email: js.js2017@gmail.com
}

\begin{abstract}
Abstrak
Salmonella typhi merupakan bakteri batang Gram negatif yang menjadi penyebab enteric fever atau demam tifoid. Deteksi dini terhadap adanya IgM anti S.typhi merupakan tantangan dalam penegakan diagnosis di laboratorium. Penelitian ini bertujuan mengetahui perbedaan hasil dari pemeriksaan IgM anti Salmonella typhi dengan menggunakan metode ICT (Immunochromatogrhafi) dan ELISA pada pasien Widal positif. Sampel dari penelitian ini sebanyak 45 yang diambil dari sisa serum pasien yang terdiagnosis Widal positif. Hasil dari penelitian ini adanya tingkat kesesuaian antara uji ICT (Immunochromatogrhafi) dengan menggunakan Rapid Thypidot IgM Salmonella typhi dan ELISA menggunakan teknik indirect ELISA dengan nilai Kappa 0,509 sehingga menunjukkan tingkat kesesuaian yang sedang.
\end{abstract}

Kata kunci : Salmonella typhi, ICT, ELISA, Widal positif.

\section{PENDAHULUAN \\ Salmonella typhi merupakan patogen} fakultatif intraseluler yang memerlukan faktor virulensi untuk tetap hidup di dalam sel agar berhasil berkolonisasi dan bereplikasi masuk ke dalam jaringan (Cheminay et al., 2005). Salmonella typhi merupakan salah satu penyebab penyakit infeksi tersering di daerah tropis (Hanna et al., 2005).

Salmonella typhi merupakan bakteri batang Gram negatif yang menjadi penyebab enteric fever atau demam tifoid. Salmonella typhi bersifat patogen pada manusia. WHO mencatat secara global bahwa insidensi demam tifoid adalah 21 juta kasus setiap tahunnya. Angka kematian insidensi global tersebut mencapai 1-4 \% dan 90\% kematian tersebut terjadi di Asia. Kasus-kasus pada daerah endemis cenderung untuk mengalami kegagalan pengobatan terhadap beberapa antibiotik yang disebut Multi-Drugs Resistance (WHO, 2008).

Salmonella typhi adalah bakteri patogen yang khusus menyerang manusia dan dalam perkembangannya demam tifoid telah menyebabkan banyak kematian di seluruh dunia, terutama pada negara berkembang seperti Indonesia.

Pemeriksaan laboratorium untuk menegakkan diagnosis demam tifoid secara garis besar dapat dibedakan menjadi empat kelompok yaitu (1) pemeriksaan darah tepi, (2) pengisolasian kuman penyebab demam tifoid S.typhi dengan biakan kuman, (3) pemeriksaan serologi untuk mendeteksi antibodi terhadap antigen $S$. typhi dan penentuan adanya antigen spesifik dari S. typhi dan (4) pelacakan DNA kuman S. typhi. 
Diagnosis pasti dapat dilakukan dengan menggunakan biakan kuman dari darah, urin, feses, sumsum tulang, cairan duodenum atau dari rose spots. Pada beberapa penelitian didapatkan biakan darah terhadap $S$. typhi tergantung dari saat pengambilan pada perjalanan penyakit. Persentase terdeteksinya kuman antara $70-90 \%$ pada minggu pertama sakit, dan positif $50 \%$ pada akhir minggu ketiga. Pada pemeriksaan kultur darah, ketidakefektifan ditemukan pada penderita demam tifoid yang sebelumnya telah mendapat antibiotik, sehingga menghambat pertumbuhan kuman dalam media biakan dan hasil kultur menjadi negatif. Volume darah terlalu sedikit (kurang dari $5 \mathrm{cc}$ ) juga dapat mengakibatkan pembacaan hasil kultur menjadi negatif. Riwayat vaksinasi dapat menimbulkan antibodi pada darah pasien yang dapat menekan bakteriemia hingga kultur darah menjadi negatif (Tumbelaka, 2003).

Walaupun spesifisitasnya tinggi, pemeriksaan kultur mempunyai sensitivitas yang rendah dan adanya kendala berupa lamanya waktu yang dibutuhkan (5-7 hari) serta peralatan yang lebih canggih untuk identifikasi bakteri sehingga tidak praktis dan tidak tepat untuk dipakai sebagai metode diagnosis baku dalam pelayanan penderita (Hayat, 2011).

\begin{tabular}{ccc}
\multicolumn{3}{c}{ Pemeriksaan lain adalah pemeriksaan } \\
serologis yaitu pemeriksaan Widal,
\end{tabular} pemeriksaan metode Dot Enzym Immunoassay (Typhidot), metode Enzymelinked Immunosorbent Assay (ELISA), pemeriksaan Dipstik dan pemeriksaan Tubex. Pemeriksaan Widal merupakan metode serologi yang banyak dilakukan di Indonesia namun sulit untuk dijadikan pegangan karena belum ada kesepakatan standar aglutinasi (cut-off point). Belum ditemukan adanya kesamaan pendapat tentang titer aglutinin yang bermakna untuk diagnosis demam tifoid. Batas titer aglutinin yang sering digunakan hanya kesepakatan saja, berlaku setempat, dan bahkan dapat berbeda di berbagai laboratorium. Selain itu, sensitivitas pemeriksaan Widal hanya $74 \%$ dan spesifisitas $17 \%$ (Marleni, 2012).
Berbagai metode diagnostik sebagai pengganti pemeriksaan Widal dan kultur darah sebagai metode konvensional masih memerlukan penelitian lebih lanjut. Beberapa metode diagnostik yang lebih cepat, mudah dilakukan dan terjangkau harganya untuk negara berkembang dengan sensitivitas dan spesifisitas yang cukup baik, seperti pemeriksaan Tubex, Typhidot dan Dipstik mulai dapat dikembangkan penggunaannya di Indonesia (Tumbelaka, 2003).

Pendeteksian dini antibodi anti S.typhi masih belum maksimal, penyebabnya adalah titer antibodi yang rendah saat pemeriksaan laboratorium sehingga berdampak pada kurang maksimalnya hasil diagnosis yang didapat. Berbagai metode yang dipergunakan dengan mempertimbangkan sensitivitas dan spesifitas yaitu dengan uji imunokromatografi (ICT) dengan menggunakan Typhidot IgM anti Salmonella typhi dan uji ELISA (Enzyme Linked Immunosorbent Assay). Dimana imunokromatografi (ICT) menggunakan Typhidot IgM anti Salmonella typhi merupakan Pemeriksaan Typhidot yang dimodifikasi. Pada kasus reinfeksi, respon imun sekunder (IgG) teraktivasi berlebihan dan IgM sulit terdeteksi. IgG dapat bertahan sampai 2 tahun sehingga pendeteksian $\operatorname{IgG}$ saja tidak dapat digunakan untuk membedakan antara infeksi akut dengan kasus reinfeksi pada kasus pemeriksaan primer. Untuk mengatasi masalah tersebut, pemeriksaan Typhidot IgM anti Salmonella typhi mampu menginaktivasi total $\mathrm{IgG}$ pada sampel serum. Pemeriksaan Typhidot IgM anti Salmonella typhi, memungkinkan ikatan antara antigen dengan IgM spesifik yang ada pada serum pasien (Hayat, 2011).

Typhidot telah dievaluasi di banyak daerah endemik demam tifoid di seluruh dunia seperti Indonesia, Malaysia, Pakistan dan Philipina. Pada penelitian Gopalakhrisnan dkk (2002) didapatkan sensitivitas pemeriksaan ini sebesar $98 \%$, spesifisitas sebesar 76,6\% dan efisiensi pemeriksaan sebesar $84 \%$. Pada penelitian lain yang dilakukan oleh Karen $\mathrm{H}$ dkk di tahun 2011 sensitivitas dan spesifisitas 
Jurnal Biosains Pascasarjana Vol. 17 (2015) pp

(C) (2015) Program Pascasarjana Universitas Airlangga, Indonesia

Typhidot yaitu $75 \%$ dan $67 \%$ (Tumbelaka, 2003; WHO, 2003).

Sedangkan uji ELISA (Enzyme Linked Immunosorbent Assay) merupakan pemeriksaan serologis yang sering dipakai untuk menganalisis adanya interaksi antigenantibodi di dalam suatu sampel dengan menggunakan enzim (WHO, 2003). Menurut Ismail dalam penelitiannya tahun 2000 pemeriksaan ini memiliki spesifisitas $95 \%$, namun memiliki kelemahan dimana besar kemungkinan terjadinya false positive karena adanya reaksi silang antara antigen yang satu dengan yang lain, sedangkan hasil false negative terjadi jika pemeriksaan ini dilakukan pada window period (waktu pembentukan antibodi baru dimulai sehingga jumlah antibodi tersebut masih sedikit dan kemungkinan tidak dapat terdeteksi). Walaupun hasil pemeriksaan ELISA lebih baik dari Widal, namun perlu dipertimbangkan karena adanya nilai positif pada kasus brusellosis (Marleni, 2012).

Berbagai penelitian mengenai sensitifitas dan spesifisitas pemeriksaan yang bervariasi mendorong keinginan penulis untuk mengetahui perbandingan pemeriksaan IgM Anti Salmonella typhi dengan metode ICT (Imunochromatogrraphy) dan ELISA (Enzyme-linked Immunosorbent Assay) pada pasien Widal positif.

Tujuan penelitian ini adalah menjelaskan perbandingkan hasil pemeriksaan metode ICT dan ELISA pada demam tifoid dan mengetahui perbedaan hasil antara metode ICT dengan ELISA pada pemeriksaan IgM anti Salmonella typhi pada pasien Widal positif.

Dengan menggunkan metode ICT dan ELISA tidak ada perbedaan hasil dalam pemeriksaan IgM anti Salmonella typhi pada pasien dengan Widal positif.

\section{METODE PENELITIAN}

Jenis penelitian ini adalah penelitian observasional analisis dengan rancangan penelitian cross sectional study. Populasi dalam penelitian ini adalah semua pasien yang terdiagnosis Widal positif. Sampel penelitian ini adalah spesimen dari pasien terdiagnosis Widal positif. Dengan kriteria inklusi yaitu Widal positif dengan titer $1 / 80,1 / 160,1 / 320$ dan semua umur $<50$ tahun. Sedangkan untuk kriteria eksklusi yaitu RA, SLE, dan penyakit Autoimun lainnya. Jumlah sampel dalam penelitian ini sebanyak 45 sampel serum pasien yang terdiagnosis Widal positif. Pengambilan sampel dilakukan secara consecutive sampling. Pengambilan sampel akan dihentikan bila telah mencapai sejumlah sampel penelitian atau jumlah sampel minimal terpenuhi.

Bahan yang digunakan pada penelitian ini adalah serum dari pasien yang terdiagnosis Widal positif, pemeriksaan ICT menggunakan Typhidot Rapid IgM $50 \mathrm{kDa} S$. typhi dan kit ELISA merupakan sampel larutan pengencer (diluents), larutan buffer (wash concentrate), konjugat enzim, substrat TMB, kalibrator, kontrol positif, kontrol negatif, dan stop solution.

Instrument penelitian ini adalah tabung sentrifuge, tabung eppendorf $1 \mathrm{ml}$, mikropipet dan tips, sentrifuge, freezer/refrigator, timer, washer ELISA dan ELISA reader $(450 \mathrm{~nm})$.

Penelitian ini dilaksanakan di laboratorium patologi klinik RSUD Dr. Soetomo Surabaya. Penelitian dilaksanakan pada bulan Mei-Juli 2015.

\subsection{Pengumpulan spesimen}

Serum untuk pemeriksaan didapatkan dari pasien dengan Widal positif $(1 / 80,1 / 160$ dan 1/320) yang sudah diterima oleh laboratorium rumah sakit Soewandi Surabaya. Kemudian darah vena disentrifus dengan kecepatan $5000 \mathrm{rpm}$ selama 10 menit dengan suhu ruangan. Supernatant diambil secara hatihati sehingga jika terjadi resuspensi maka dilakukan sentrifugasi lagi. Supernatant yang telah diambil langsung dapat digunakan atau disimpan pada $-20^{\circ} \mathrm{C}$ atau disimpan pada temperature $4^{\circ} \mathrm{C}$ dengan ditambahkan sodium azide $0,02 \%$. 
Jurnal Biosains Pascasarjana Vol. 17 (2015) pp

(C) (2015) Program Pascasarjana Universitas Airlangga, Indonesia

\subsection{Prosedur pengumpulan data dari pemeriksaan ICT}

ICT yang digunakan pada penelitian ini yaitu untuk pemeriksaan IgM anti Salmonella typhi (Typhidot Rapit IgM Salmonella typhi). Adapun cara pemeriksaannya yaitu meneteskan $30-35 \mu 1$ spesimen di sumuran persegi. Selanjutnya meneteskan Buffer di sumuran oval, dan terakhir menarik plastik untuk melihat hasil dalam 15 menit. Hasil dinyatakan positif bila terdapat dua garis dan dinyatakan negatif bila terdapat satu garis yang langsung dilihat pada alat tersebut.

\subsection{Prosedur pengumpulan data dari pemeriksaan ELISA}

Teknik ELISA yang digunakan dalam penelitian ini adalah untuk pemeriksaan IgM anti Salmonella typhi. Adapun cara pemeriksaan IgM anti Salmonella typhi adalah semua spesimen dan kit ELISA ke suhu ruangan $\left(18^{0}-26^{\circ} \mathrm{C}\right)$ secara perlahan. Selanjutnya diberi nomer atau kode sampel, kontrol positif, kontrol negatif pada sisi pegangan dari lapisan strip sumur masingmasing. Setelah itu, kontrol negatif, kontrol positif dan kalibrator siap untuk digunakan. Selanjutnya siapkan 1:101 larutan sampel, dengan menambahkan $5 \mu$ l serum ke dalam $0,5 \mathrm{ml}$ larutan pengencer sampel (sampel diluent), lalu campur rata. Kemudian larutan sampel, kalibrator, kontrol positif, dan kontrol negatif, masing-masing dipipet $100 \mu \mathrm{l}$, kemudian dimasukkan ke dalam sumur sesuai kode masing-masing. Kemudian untuk blanko reagen dipipet $100 \quad \mu l$ larutan pengencer sampel dimasukkan ke dalam sumur $1 \mathrm{~A}$, setelah itu diinkubasi selama 20 menit pada suhu ruang. Selanjutnya kelebihan cairan pada seluruh sumur dibuang. Kemudian masingmasing sumur dicuci sebanyak tiga kali masing-masing dengan $300 \mu \mathrm{l}$ buffer, setelah itu cairannya dibuang dengan membalikkan posisi plate dan menekan-nekannya diatas bantalan tisu. Kemudian masing-masing sumur ditambahkan $100 \mu \mathrm{l}$ konjugat enzim. Kemudian diinkubasi selama 20 menit pada suhu ruang. Selanjutnya kelebihan cairan pada seluruh sumur dibuang, kemudian masing- masing sumur dicuci sebanyak tiga kali masing-masing dengan $300 \mu \mathrm{l}$ buffer, setelah itu cairannya dibuang dengan membalik posisi plate dan menekan-nekannya diatas bantalan tissue. Kemudian masing-masing sumur ditambahkan $100 \mu 1$ substrat TMB, setelah itu diinkubasi selama 10 menit pada suhu ruang. Selanjutnya masing-masing sumur ditambahkan $100 \mu 1$ stop solution. Kemudian baca OD pada panjang gelombang $450 \mathrm{~nm}$ menggunakan ELISA reader dalam 15 menit. Hasil dinyatakan sebagai negatif dan positif berdasarkan indeks antibodi yaitu nilai hasil dari OD sampel dibagi dengan nilai cut off. Nilai cut off ditentukan berdasarkan OD kalibrator dikali dengan kalibrator faktor. Indeks antibodi ELISA berkisar dari $<0,9$ (negatif) dan > 1,1 (positif) (Calbiotech, 2014).

Data yang diperoleh pada masingmasing variabel disajikan secara deskriptif dan dalam bentuk table dan grafik. Data dianalisis dengan menggunakan uji Kappa.

\section{HASIL DAN PEMBAHASAN 3.1. Data Penelitian}

Pada tahap awal penelitian dilakukan pengumpulan sampel sebanyak 45 sampel, yang terdiri dari laki-laki sebanyak 17 orang dan perempuan sebanyak 28 orang dengan rentang usia 1-49 tahun.

Tahap berikutnya yaitu pemeriksaan IgM anti S.typhi dengan metode ICT dengan menggunakan kit Rapid Typidot IgM Salmonella typhi dari PT NELTA MULTI GRACIA bekerja sama dengan Reszon Diagnostics Internasional. Hasil pemeriksaan dinyatakan berdasarkan garis yang terlihat, dimana dinyatakan negatif bila terdapat satu garis saja dan positif bila terdapat dua garis. Selanjutnya dilakukan pemeriksaan yang kedua dengan metode ELISA menggunakan teknik Indirect ELISA yang terdapat di kit ELISA S.typhi IgM human dari Calbiotech, dimana hasilnya dinyatakan dengan indeks antibodi (indeks $\mathrm{Ab}$ ), dimana indeks $\mathrm{Ab}<0,9$ dikatakan negatif dan indeks $\mathrm{Ab}>1,1$ dinyatakan positif. 
Jurnal Biosains Pascasarjana Vol. 17 (2015) pp

(C) (2015) Program Pascasarjana Universitas Airlangga, Indonesia

\subsection{Analisis dan Hasil Penelitian}

\subsubsection{Hasil Analisis Deskriptif Usia Pasien}

Hasil analisis statistik deskriptif usia pasien dapat dilihat pada tabel 5.1 dibawah ini, sebagai berikut:

\section{Tabel 5.1 Hasil Analisis Statistik Deskriptif Usia Pasien}

\begin{tabular}{|l|c|c|c|c|c|}
\hline & $\mathbf{N}$ & $\begin{array}{c}\text { Mi } \\
\mathbf{n}\end{array}$ & $\begin{array}{c}\text { Ma } \\
\mathbf{k}\end{array}$ & Mean & SD \\
\hline $\begin{array}{l}\text { Umu } \\
\text { r }\end{array}$ & 4 & 1 & 49 & 17,337 & 10,9948 \\
2 & & & 1 & 2 \\
\hline
\end{tabular}

Jumlah pasien sebanyak 45 dengan umur pasien termuda adalah 1 tahun dan umur pasien tertua adalah 49 tahun dengan umur rata-rata 17 tahun \pm 11 tahun.

\subsubsection{Hasil analisis deskriptif jenis kelamin}

Presentase jenis kelamin pada pasien dapat dilihat pada tabel 5.2 dibawah ini, sebagai berikut:

Tabel 5.2 Presentase Jenis Kelamin Pasien

\begin{tabular}{|c|c|c|}
\hline & Frekuensi & Persentase \\
\hline Laki-laki & 17 & 37,8 \\
\hline Perempuan & 28 & 62,2 \\
\hline Total & 45 & 100 \\
\hline
\end{tabular}

Jenis kelamin pada pasien adalah laki-laki sebanyak 17 orang dengan persentase $(37,8 \%)$ dan perempuan sebanyak 28 orang dengan presentae $(62,2 \%)$.

\subsubsection{Hasil analisis deskriptif Antigen 0}

Presentase untuk hasil analisis Antigen $\mathrm{O}$ dapat dilihat pada table 5.3 dibawah ini, sebagai berikut:

Tabel 5.3 Hasil Analisis Deskriptif Antigen O

\begin{tabular}{|c|c|c|}
\hline & Frekuensi & Persentase \\
\hline Negatif & 12 & 26,7 \\
\hline 80 & 15 & 33,3 \\
\hline 160 & 12 & 26,7 \\
\hline 320 & 6 & 13,3 \\
\hline Total & 45 & 100 \\
\hline
\end{tabular}

Berdasarkan data pada tabel 5.3 diatas dapat dijelaskan untuk hasil deskriptif Antigen $\mathrm{O}$ yaitu hasil dari titer yang negatif dan titer 160 sebanyak 12 (26,7\%), dan titer 80 sebanyak $15(33,3 \%)$, sedangkan titer 320 sebanyak $6(13,3 \%)$.

\subsubsection{Hasil analisis deskriptif Antigen $H$}

Persentase untuk hasil analisis Antigen $\mathrm{H}$ dapat dilihat pada tabel 5.4 dibawah ini, sebagai berikut:

Tabel 5.4 Hasil Analisis Deskriptif Antigen

H

\begin{tabular}{|c|c|c|}
\hline & Frekuensi & Persentase \\
\hline Negatif & 15 & 33,3 \\
\hline 80 & 10 & 22,2 \\
\hline 160 & 7 & 15,6 \\
\hline 320 & 13 & 28,9 \\
\hline Total & 45 & 100 \\
\hline
\end{tabular}

Berdasarkan data pada tabel 5.4 diatas dapat dijelaskan untuk hasil deskriptif antigen $\mathrm{H}$ yaitu hasil dari titer yang negatif sebanyak $15(33,3 \%)$, untuk titer 80 sebanyak $10(22,2 \%)$ dan titer 160 sebanyak $7(15,6 \%)$, serta pada titer 320 sebanyak 13 (28,9\%).

\subsubsection{Analisis hasil pemeriksaan IgM anti S.typhi dengan menggunakan kit ICT}

Hasil pemeriksaan IgM anti S.typhi dengan menggunakan kit ICT dapat dilihat pada tabel 5.5 dibawah ini, sebagai berikut:

Tabel 5.5 Hasil Analisis Pemeriksaan IgM anti S.typhi menggunakan kit ICT

\begin{tabular}{|c|c|c|}
\hline & ICT & Persentase \\
\hline Positif & 26 & 57,8 \\
\hline Negatif & 19 & 42,2 \\
\hline Total & 45 & 100 \\
\hline
\end{tabular}

Berdasarkan tabel 5.5 diatas didapatkan hasil pemeriksaan menggunakan kit ICT dari sampel serum 45 orang dengan Widal positif menunjukkan $26(57,8 \%)$ sampel positif dan $19(42,2 \%)$ sampel negatif. 
Jurnal Biosains Pascasarjana Vol. 17 (2015) pp

(C) (2015) Program Pascasarjana Universitas Airlangga, Indonesia

\subsubsection{Hasil Analisis Pemeriksaan IgM Anti S.typhi Menggunakan Kit ELISA}

Hasil pemeriksaan IgM anti S.typhi dengan menggunakan kit ELISA dapat dilihat pada tabel 5.6 dibawah ini, sebagai berikut:

Tabel 5.6 Hasil Analisis Pemeriksaan IgM Anti S.typhi Menggunakan kit ELISA

\begin{tabular}{|c|c|c|}
\hline & ELISA & Persentase \\
\hline Negatif & 22 & 48,9 \\
\hline $\begin{array}{c}\text { Borderline } \\
\text { positif }\end{array}$ & 4 & 8,9 \\
\hline Positif & 19 & 42,2 \\
\hline Total & 45 & 100 \\
\hline
\end{tabular}

Berdasarkan tabel 5.6 diatas didapatkan hasil pemeriksaan dengan kit ELISA menunjukkan $19 \quad(42,2 \%)$ sampel positif dan $22(48,9 \%)$ sampel negatif serta 4 $(8,9 \%)$ diantaranya menunjukkan hasil BLP (Borderline Positif).

\subsubsection{Hasil Tabulasi Silang antara Antigen $\mathrm{O}$ dengan kit ICT}

Hasil tabulasi silang antara Antigen O dengan kit ICT dapat dilihat pada tabel 5.7 dibawah ini, sebagai berikut:

Tabel 5.7. Hasil Tabulasi Silang Antara Antigen $O$ dengan kit ICT

\begin{tabular}{|c|c|c|c|c|c|c|c|}
\hline \multirow{2}{*}{} & \multicolumn{5}{|c|}{ ICT } & $\begin{array}{c}\text { T } \\
\text { ot }\end{array}$ & $\begin{array}{c}\text { Per } \\
\text { sent } \\
\text { ase } \\
\text { an }\end{array}$ \\
\cline { 2 - 7 } \multicolumn{2}{|c|}{} & $\begin{array}{c}\text { Ne } \\
\text { ga } \\
\text { tif }\end{array}$ & $\begin{array}{c}\text { Per } \\
\text { sent } \\
\text { ase }\end{array}$ & $\begin{array}{c}\text { P } \\
\text { os } \\
\text { iti } \\
\text { f }\end{array}$ & $\begin{array}{c}\text { Per } \\
\text { sent } \\
\text { ase }\end{array}$ & & \\
\hline $\begin{array}{c}\text { An } \\
\text { tig } \\
\text { en } \\
\text { O }\end{array}$ & $\begin{array}{c}\text { Ne } \\
\text { ga } \\
\text { tif }\end{array}$ & 4 & 21,1 & 8 & 30,8 & 1 & 26,7 \\
& $\begin{array}{c}\mathbf{1} \\
\mathbf{8 0}\end{array}$ & 9 & 47,4 & 6 & 23,1 & 1 & 33,3 \\
& $\begin{array}{c}\mathbf{1} \\
\mathbf{1 6} \\
\end{array}$ & 5 & 26,3 & 7 & 26,9 & 1 & 26,7 \\
& $\mathbf{0}$ & & & & & 2 & \\
\cline { 2 - 7 } & $\mathbf{1 /}$ & 1 & 5,3 & 5 & 19,2 & 6 & 13,3 \\
& $\begin{array}{c}\mathbf{3 2} \\
\mathbf{0}\end{array}$ & & & & & & \\
\hline \multirow{2}{*}{$\begin{array}{c}\text { To } \\
\text { tal }\end{array}$} & & 19 & 100 & 26 & 100 & 4 & 100 \\
\hline
\end{tabular}

Regresi logistik sederhana; $\mathrm{p}=0,390$

Dari tabel 5.7 dapat dijelaskan bahwa hasil analisis tabulasi silang antara Antigen $\mathrm{O}$ dan kit ICT (Rapid Thypidot IgM Salmonella typhi) yaitu untuk titer $1 / 80$ sebanyak 9 $(47,4 \%)$ negatif dan $6(23,1 \%)$ positif, untuk titer yang 160 sebanyak $5(26,3 \%)$ negatif dan $7(26,9 \%)$ positif, untuk titer 320 sebanyak 1 $(5,3 \%)$ negatif dan $5(19,2 \%)$ positif, sedangkan untuk yang negatif terdapat 4 $(21,1 \%)$ negatif dan $8(30,8 \%)$ positif serta dengan nilai $\mathrm{p}=0,390$ sehingga tidak signifikan.

\subsubsection{Hasil Tabulasi Silang Antara Antigen $\mathrm{H}$ dengan kit ICT}

Hasil tabulasi silang antara Antigen $\mathrm{H}$ dengan kit ICT dapat dilihat pada tabel 5.8 dibawah ini, sebagai berikut:

Tabel 5.8. Hasil tabulasi silang antara Antigen $\mathrm{H}$ dengan kit ICT

\begin{tabular}{|c|c|c|c|c|c|c|c|}
\hline & \multicolumn{4}{|c|}{ ICT } & \multirow{2}{*}{$\begin{array}{c}T \\
\text { ot } \\
\text { al }\end{array}$} & \multirow{2}{*}{$\begin{array}{c}\text { Per } \\
\text { sent } \\
\text { ase }\end{array}$} \\
\hline & & $\begin{array}{l}\mathrm{Ne} \\
\text { ga } \\
\text { tif }\end{array}$ & $\begin{array}{c}\text { Per } \\
\text { sent } \\
\text { ase }\end{array}$ & $\begin{array}{l}\mathbf{P} \\
\text { os } \\
\text { iti } \\
\mathbf{f}\end{array}$ & $\begin{array}{c}\text { Per } \\
\text { sent } \\
\text { ase }\end{array}$ & & \\
\hline \multirow{4}{*}{$\begin{array}{l}\text { An } \\
\text { tig } \\
\text { en } \\
\text { H }\end{array}$} & $\begin{array}{l}\mathrm{Ne} \\
\text { ga } \\
\text { tif }\end{array}$ & 11 & 57,9 & 4 & 15,4 & $\begin{array}{l}1 \\
5\end{array}$ & 33,3 \\
\hline & $\begin{array}{l}1 / \\
80\end{array}$ & 4 & 21,1 & 6 & 23,1 & $\begin{array}{l}1 \\
0\end{array}$ & 22,2 \\
\hline & $\begin{array}{c}1 / \\
16 \\
0 \\
\end{array}$ & 2 & 10,5 & 5 & 19,2 & 7 & 15,6 \\
\hline & $\begin{array}{c}1 / \\
32 \\
0\end{array}$ & 2 & 10,5 & 11 & 42,3 & $\begin{array}{l}1 \\
3\end{array}$ & 28,9 \\
\hline $\begin{array}{l}\text { To } \\
\text { tal }\end{array}$ & & 19 & 100 & 26 & 100 & $\begin{array}{l}4 \\
5\end{array}$ & 100 \\
\hline
\end{tabular}

Regresi logistik sederhana; $\mathrm{p}=0,006$

Dari tabel 5.8 dapat dijelaskan bahwa hasil analisis tabulasi silang antara Antigen $\mathrm{O}$ dan kit ICT (Rapid Thypidot IgM Salmonella typhi) yaitu untuk titer 80 sebanyak $4(21,1 \%)$ negatif dan $6(23,1 \%)$ positif, untuk titer yang 160 sebanyak $2(10,5 \%)$ negatif dan $5(19,2 \%)$ positif, untuk titer 320 sebanyak $2(10,5 \%)$ 
negatif dan $11(42,3 \%)$ positif, sedangkan untuk yang negatif terdapat $11(57,9 \%)$ negatif dan $4(15,4 \%)$ positif serta dengan nilai $\mathrm{p}=$ 0,006 sehingga ada keterkaitan hubungan (signifikan).

\subsubsection{Analisis statistik hasil positif dan negatif pemeriksaan IgM anti S.typhi menggunkan kit ICT dan ELISA}

Dengan melakukan tabulasi silang dari hasil pemeriksaan IgM anti S.typhi menggunakan kit ICT (Rapid Thypidot IgM Salmonella typhi) dan ELISA didapatkan hasil seperti yang dilihat pada tabel 5.9, sebagai berikut:

Tabel 5.9. Analisis Statistik Hasil Positif dan Negatif Pemeriksaan IgM anti S.typhi menggunkan kit ICT (Rapid Thypidot IgM Salmonella typhi) dan ELISA

\begin{tabular}{|c|c|c|c|c|c|c|c|}
\hline & \multicolumn{4}{|c|}{ ICT } & \multirow{2}{*}{$\begin{array}{l}\text { T } \\
\text { ot } \\
\text { al }\end{array}$} & \multirow{2}{*}{$\begin{array}{c}\text { Pers } \\
\text { enta } \\
\text { se }\end{array}$} \\
\hline & & $\begin{array}{c}\text { P } \\
\text { o } \\
\text { si }\end{array}$ & $\begin{array}{c}\text { Pers } \\
\text { enta } \\
\text { se }\end{array}$ & $\begin{array}{l}\mathbf{N} \\
\text { eg } \\
\mathbf{a}\end{array}$ & $\begin{array}{c}\text { Pers } \\
\text { enta } \\
\text { se }\end{array}$ & & \\
\hline \multirow{2}{*}{$\begin{array}{c}\text { EL } \\
\text { IS } \\
\text { A }\end{array}$} & $\mathbf{P}$ & $\begin{array}{l}1 \\
9\end{array}$ & 42,2 & 4 & 8,9 & 23 & 51,1 \\
\hline & $\mathbf{N}$ & 7 & 15,6 & 15 & 33,3 & 22 & 48,9 \\
\hline \multicolumn{2}{|c|}{ Total } & $\begin{array}{l}2 \\
6\end{array}$ & 57,8 & 19 & 42,2 & 45 & 100 \\
\hline
\end{tabular}

Kappa $=0,509 ; p=0,001$

$\begin{array}{ccc}\text { Dari hasil uji kesesuaian } & \text { Kappa } \\ \text { dilakukan untuk mengetahui tingkat }\end{array}$ kesesuaian antara hasil kit ICT dan ELISA. Nilai Kappa yang didapatkan adalah 0,509. Nilai ini menunjukkan bahwa hasil ICT dan ELISA memiliki tingkat kesesuaian yang sedang. Sedangkan nilai $\mathrm{p}$ didapatkan 0,001 $(<0,05)$, menunjukkan bahwa hasil ICT dan ELISA memiliki tingkat kesesuaian secara bermakna (signifikan).

Pendeteksi dini terhadap adanya IgM anti S.typhi merupakan tantangan dalam penegakan diagnosis di laboratorium pada kasus demam tifoid. Salah satu penyebabnya adalah masih rendahnya kadar antibodi IgM saat pemeriksaan di laboratorium.
Pada penelitian ini dilakukan perbandingan pemeriksaan IgM anti S.typhi dengan menggunakan kit ICT yang mendeteksi IgM anti OMP S.typhi dengan Rapid Thypidot IgM Salmonella typhi dan ELISA yang mendeteksi IgM anti LPS S.typhi dengan metode Indirect ELISA.

Dari total sampel yang diujikan pada penelitian ini didapatkan hasil bahwa sampel yang berasal dari pasien laki-laki sebanyak 17 $(37,8 \%)$ dan perempuan sebanyak $28(62,2 \%)$ dengan rentang usia bervariasi yakni umur termuda 1 tahun dan yang tertua 49 tahun, dengan umur rata-rata 17 tahun \pm 11 tahun.

Dari hasil penelitian ini juga diperoleh antigen $\mathrm{O}$ dan $\mathrm{H}$, dimana hasil dari antigen $\mathrm{O}$ dengan titer yang negatif dan titer 160 sebanyak $12(26,7 \%)$, dan titer 80 sebanyak $15(33,3 \%)$, sedangkan titer 320 sebanyak $6(13,3 \%)$. Sedangkan hasil dari antigen $\mathrm{H}$ dengan titer yang negatif sebanyak $15(33,3 \%)$, untuk titer 80 sebanyak 10 $(22,2 \%)$ dan titer 160 sebanyak $7(15,6 \%)$, serta pada titer 320 sebanyak 13 (28,9\%).

Dari pemeriksaan yang sudah dilakukan dengan menggunakan kit ICT (Rapid Thypidot IgM Salmonella typhi) pada pemeriksaaan IgM anti S.typhi didapatkan hasil yang menunjukkan $26(57,8 \%)$ sampel positif dan $19(42,2 \%)$ sampel negatif. Sedangkan hasil pemeriksaan dengan menggunkan kit ELISA didapatkan hasil yang menunjukkan $19(42,2 \%)$ sampel positif dan $22(48,9 \%)$ sampel negatif serta sisanya 4 $(8,9 \%)$ mengalami Borderline positif.

Hasil yang diperoleh antara kedua pemeriksaan ini tidak sesuai dengan pemeriksaan serupa yang pernah dilakukan oleh peneliti lain, dimana terdapat kesesuaian yang sangat baik antara hasil pemeriksaaan ICT dan ELISA dengan hasil sensitifitas dan spesifitas yang sama (Lim et all.,1998).

Dengan gambaran hasil pemeriksaan uji ELISA nampak bahwa persentase yang positif demam tifoid cukup banyak yaitu 19 $(42,2 \%)$ sampel. Hal ini mungkin disebabkan oleh nilai cut off tinggi dan sampel yang diperiksa kadar antibdi IgG anti S.typhi tinggi. 
Menurut Suwarno (2010), absorbsi antigen terlalrut pada fase padat merupakan faktor utama yang menentukan sensitivitas suatu asai ELISA. Indonesia merupakan daerah endemik tifoid, dimana kadar IgG anti S.typhi pada populasi cukup tinggi. Tingginya kadar IgG ini dapat menghambat reaksi IgM dengan antigen S.typhi pada ELISA. Jadi untuk desain ELISA sebaiknya dipakai metode Indirect Capture ELISA IgG diikat terlebih dahulu pada fase padat.

Pada uji ELISA hasil positif atau negatif ditentukan dari besar kecilnya indeks antibodi. Deteksi pada ELISA menggunkan ELISA reader dengan detektor khusus sehingga menghasilkan nilai yang akurat. Munculnya hasil angka yang pasti ini menjadi kelebihan uji ELISA jika dibandingkan dengan uji ICT. Hasil pemeriksaan positif pada ICT bisa menghasilkan negatif pada uji ELISA, hal ini memungkinkan disebabkan ICT memiliki keterbatasan akurasi karena pembacaan hanya memerlukan mata sehingga bisa menghasilkan positif palsu. Hal ini terjadi terutama pada kadar IgM rendah yang hanya memunculkan garis.

Selain itu hasil positif pada pemeriksaan ICT juga dapat disebabkan akibat infeksi bakteri Salmonella non tifoid seperti infeksi Salmonella enterica serotype enteridis, spesies bakteri lain dan pada kondisi lain seperti malaria, gangguan imunologis, penyakit hati kronik serta hasil dari pengobatan antibiotik yang tidak tepat (Dong, 2007; Olsen, 2004).

Reaksi dasar dari ICT dan ELISA adalah reaksi imunologis antara antibodi dalam serum dengan antigen spesifik dalam alat. Reaksi imunologis yang terjadi dalam alat ICT yaitu Rapid Thypidot Salmonella typhi. Sedangkan reaksi imunologis yang terjadi dalam alat ELISA adalah Indirect ELISA. Walupun kedua alat tersebut sama-sama menggunakan antigen spesifik terhadap antibodi IgM, namun setiap pabrik tentu mengembangkan sendiri antigennya sehingga dapat memiliki tingkat sensitivitas dan spesifisitas tertentu. Terjadinya hambatan pada reaksi imunologis sangat mempengaruhi hasil.
Menurut Suwarno (2010), yang dapat menyebabkan terjadinya hambatan pada reaksi imunologis antara lain adalah adanya antibodi heterofil, antibodi non spesifik lain, faktor rheumatoid. Hal ini bisa menimbulkan negatif palsu atau positif palsu.

Dari uji Kappa didapatkan tingkat kesesuaian yang sedang yaitu 0,509. Menurut Dahlan (2014), interpretasi nilai Kappa dan tingkat kesesuaian bervariasi dari 0,02 (sangat rendah) $\quad, 0,2-0,4 \quad$ (rendah), .0,4-0,6 (sedang).0,6-0,8 (kuat) dan .0,8-1 (sangat kuat). Dengan tingkat kesesuaian yang sedang menunjukkan uji ICT dan uji ELISA memiliki tingkat kesesuaian secara bermakna atau signifikan.

\section{Kesimpulan}

Berdasarkan hasil penelitian dapat disimpulkan, sebagai berikut:

1. Ada perbedaan hasil antara pemeriksaan IgM anti Salmonella typhi dengan menggunkan metode ICT dan ELISA pada pasien Widal positif.

2. Terdapat tingkat kesesuaian yang baik antara hasil uji ICT menggunkan Rapid Thypidot IgM Salmonella typhi dan ELISA pada pemeriksaan IgM anti Salmonella typhi dengan pasien Widal positif.

\section{Saran}

Perlu dilakukan penelitian lebih lanjut terhadap sampel darah pasien Widal positif dengan uji ICT menggunkan Rapid Thypidot IgM Salmonella typhi dan ELISA dengan menggunakan kultur darah sebagai baku emas untuk mendapatkan hasil sensitivitas dan spesifisitas yang maksimal terhadap kedua tes. 
Jurnal Biosains Pascasarjana Vol. 17 (2015) pp

(C) (2015) Program Pascasarjana Universitas Airlangga, Indonesia

\section{DAFTAR PUSTAKA}

Cheminay, C., A. Mohlenbrink., and M. Hansel, 2005. "Intracelluler Salmonela inhibit antigen presentation by dendritic cells." J. Immunol. 174 :2892-2899.

Hanna, Endah T., dan Hana R, 2005. "Pengaruh $\mathrm{pH}$ terhadap Pertumbuhan Salmonella typhi In Vitro." Artikel penelitian. JKM, Vol. 5 No. 1.

Hayat AS., 2011. "Evaluation of Typhidot $(\operatorname{IgM})$ in early and rapid diagnosis of typhoid fever." Professional Med. 18(2): 259-264.

Lim, PakLeong., et al." OneSte p 2 Minute Test to Dete ct TyphoidSpesific Antibo dies Based on Particle Separation in Tube." Journal of Clinical Microbiology. 1998: 2271-2278.

Marleni M., 2012. Ketepatan pemeriksaan Tubex TF dibandingkan Nested-PCR dalam mendiagnosis demam tifoid pada anak pada demam hari ke-4. Palembang: Fakultas Kedokteran Universitas Sriwijaya.

Olsen, S.J., et al., 2004. "Evaluation of Rapid Diagnostic Test for Tyhoid Fever." J. Clin. Microbiol 42(5): 1885-1889.

Suwarno, Rantam, F.A., Ernawati, R., Sianita, N., Rahardjo, A.P. and Rahmahani, J., 2010. ELISA Teori dan Protokol. Fakultas Kedokteran Hewan Universitas Airlangga, Surabaya.

Tumbelaka., 2003. "Tata Laksana Demam Tifoid Pada Anak. Pediatrics Update." Naskah lengkap Pendidikan Kedokteran Berkelanjutan Ilmu Kesehatan Anak IDAI Jaya.

World Health Organization (WHO). 2008. Typhoid fever.http://www.who.int.
WHO. The Diagnosis, Treatment, and Prevention of Thypoid Fever. Geneva : 2003. p. 11-16.

JBP Vol. 17, No. 2, Agustus 2015-Alpian Jayadi 